\title{
Tyrphostin B56
}

National Cancer Institute

\section{Source}

National Cancer Institute. Tyrphostin B56. NCI Thesaurus. Code C1780.

A member of the tyrphostin family of tyrosine kinase inhibitors, that selectively inhibits epidermal growth factor receptor kinase activity. ( $\mathrm{NCl})$ 